ORIGINAL ARTICLE

\title{
Emancipatory Racial Humor as Critical Public Pedagogy: Subverting Hegemonic Racism
}

\author{
Jonathan P. Rossing
}

Department of Communication Studies, IU School of Liberal Arts, Indiana University - Purdue University, Indianapolis, IN 46220, USA

\begin{abstract}
This essay identifies emancipatory racial humor as a disarming critical public pedagogy that confronts racial hegemony. Acknowledging the interpretive quandaries of humor and the possibilities of racist humor, this essay tells an often overlooked story of the comic "heroes" who struggle against dominant racial meanings, power relationships, and identity constructions. The essay analyzes the pedagogical possibilities of critical humorists who creatively confront hegemonic racism and whose work participates in critical projects of social, political, and cultural transformation. Such emancipatory racial humor serves as a critical public pedagogy that exposes dominant public pedagogies, injects counternarratives into the struggle over hegemony, and subverts naturalized racial meanings and privileges.
\end{abstract}

Keywords: Race/Racism, Public Pedagogy, Critical Public Pedagogy, Humor/Comedy, Critical Race Theory, Hegemony.

doi:10.1111/cccr.12126

Appearing on Comedy Central's The Daily Show with Jon Stewart for the first time, biracial South African comedian Trevor Noah joked, "I just flew in [from South Africa], and boy are my arms tired." Stewart laughed politely at the throw-away joke - “an oldie but a goodie!" But Noah's punchline only set up his knock-out blow: "No seriously. I've been holding my arms like this since I got here!" He raised his arms in the "Hands up, don't shoot" surrender pose. Noah's jabs continued. He claimed to be more afraid of the police in New York than in South Africa and joked that his experience made him "a little nostalgic for the old days back home." Noah's sharp-witted comparison between U.S. race relations and South Africa's apartheid state speaks jarringly to the persistent reality of racial oppression in U.S. culture. His punchline strikes a blow to the postracial narratives that downplay racial injustice by insisting that the scourge of racism remains in countless daily manifestations: For instance, structural oppression such as gross wealth inequalities and mass

Corresponding author: Jonathan P. Rossing; e-mail: jrossing@iupui.edu

This is the author's manuscript of the article published in final edited form as:

Rossing, J. P. (2016). Emancipatory Racial Humor as Critical Public Pedagogy: Subverting Hegemonic Racism. Communication, Culture \& Critique, 9(4), 614-632. https://doi.org/10.1111/cccr.12126 
incarceration of men and women of color; discursive constructions that mark people of color as outsiders, criminals; and psychologically violent microaggressions against racial minorities. Satirical jabs such as Noah's may not dismantle entrenched systems of racism; however, such comedic discourses play a vital role in the struggle against hegemonic racism.

A conglomeration of oppressive racial constructions and postracial ideologies saturates contemporary society; nevertheless, public culture remains the site to contest hegemonic racism. Lipsitz (1990) argues of popular culture:

On the one hand, systematic exercises of power throughout society encourage expressions in popular culture reflective of economic, racist, and sexist

hierarchies. On the other hand, oppositional traditions deeply embedded within the past and present lives of concrete historical subjects work to undermine dominant ideologies and to stimulate real and imagined alternatives. (p. 108)

Emancipatory racial humor functions as a vital participant in this struggle over knowledge, identity, power relationships, and agency. As this discussion will establish, humor proves "emancipatory" because it brings to the forefront perspectives and knowledge that challenge dominant realities, and therefore it bears potential for promoting critical questioning and reflection about racial oppression. This essay considers not why people laugh in tragic times - others have provided valuable insights into the psychology of humor (e.g., Lefcourt, 2001; Morreall, 1983). Instead, I argue that emancipatory racial humor offers a disarming pedagogical strategy for exploring social issues surrounding race and for confronting the cultural conditions spawning racial injustice. Specifically, emancipatory racial humor functions as a critical public pedagogy or "pedagogy of disruption" (Giroux, 2003, p. 78) that struggles against the dominant discourses sustaining racist hegemony. By fostering critical consciousness about racial identity, racism, and privilege, such humor could help people identify, criticize, and ultimately begin to transform hegemonic racism.

This essay provides an overview of public pedagogy and a conceptualization of critical public pedagogy before addressing racial humor's contentious continuum. In contrast to merely racist humor, certain critical pedagogical features of emancipatory racial humor resist hegemonic racial oppression. Such critical humor addresses many manifestations of racist hegemony; however, this discussion will focus on texts that confront racial oppression in the criminal justice system. This theme, appearing consistently throughout six decades of critical racial humor, exemplifies how emancipatory racial humor attends to questions of identity, privilege, and power in ways that may contribute to loosening the restraints of racial oppression and freeing culture from the control of hegemonic racism. Showcasing a range including stand-up performances, sketch comedy, and late-night news satires emphasizes emancipatory racial humor's variety. Locating this critical public pedagogy within current production and circulation practices augments emancipatory racial humor's transformative potential. Finally, emancipatory racial humor fosters community and solidarity among critical cultural workers, scholars, and educators working for transformation. 


\section{(Critical) public pedagogy}

The term "public pedagogy" appears in scholarly conversations about education as early as 1894; since 2000, however, public pedagogy has grown into a sustained program of inquiry (Sandlin, O’Malley, \& Burdick, 2011). Grounded in Gramscian cultural studies frameworks, public pedagogy recognizes culture as a contested educational space with significant political force. Public pedagogy scholarship attends to popular culture as a site of struggle over knowledge, power relationships, and identity and as the material used to (re)produce these cultural features (Hall, 1997). As such, culture serves as a site of "permanent education," where the social environment possesses an "educational force" that "actively and profoundly teaches" (Williams, 1967 , p. 15). Studying public pedagogy then means attending to the "education provided by popular culture; popular culture teaches audiences and participants through the ways it represents people and issues and the kinds of discourses it creates and disseminates" (Sandlin, 2007, p. 76). Engaging culture as pedagogical recognizes the dynamic learning that occurs and the political and material implications that emerge as social groups struggle over meaning, representation, and power in the popular culture arena (Giroux, 2001, 2011; Grossberg, 1994; Storey, 2006).

Public pedagogy provides a theoretical framework for understanding racist hegemony. Dominant public pedagogy - that is, the prevailing messages and discursive practices in public culture-enables, legitimizes, and reinforces the devaluing of people of color, condones acts of violence against racial minority groups, renders this violence invisible, and creates sanctuary for White privilege. For instance, legal and political discourses criminalize bodies of color, thereby reproducing logics of racial oppression, domination, and privilege (Alexander, 2010; Griffin, 2013; López, 2006, 2014). Racial logics embed themselves in the physical spaces people occupy (Lipsitz, 2011). Traditional educational practices reproduce oppressive racial ideologies and power relations (Darling-Hammond, 2004; Morris, 2005). Popular media disproportionately depicts racial violence against people of color (Denzin, 2003; Enck-Wanzer, 2009; Yousman, 2009). Moreover, a public pedagogy on postracialism masks, and consequently bolsters, the public pedagogy on racial domination (Griffin, 2015; Mukherjee, 2014; Squires, 2014).

Public pedagogy scholarship also recognizes performers, artists, and cultural workers as pedagogues. This scholarship investigates how people create "new and imagined possibilities through art and other cultural practices to bear witness to the ethical and political dilemmas" in their everyday lives (Giroux, 2001, p. 8). In other words, through "performative politics," cultural workers reshape culture to empower people to change their world for the better (Grossberg, 1996). Jazz, theater, rap, hip-hop, and cinema, for instance, represent sites for oppositional education, where artists confront practices of domination and imagine new possibilities for the future (Dimitriadis, 2001; hooks, 1995). To be sure, dominant groups may appropriate these oppositional voices; however, these critical projects also carry the potential to make visible dominant discourses, disrupt common sense, and struggle over identification 
and representation. As participants in ongoing struggles over hegemony, they create possibilities for reshaping material realities and power relations in ways that may disenthrall culture from oppressive practices.

Such popular sites of oppositional education represent "critical public pedagogies" (Giroux, 2000, p. 355). Like its namesake "critical pedagogy," critical public pedagogy aims (a) to deepen and expand sociopolitical agency by developing the capacity to critique conditions that sustain social inequities and (b) to animate social transformation (e.g., Freire, 2000/1970; McLaren, 1989). The development of critical consciousness proves emancipatory insofar as it develops understanding about the nature of social injustice and the practices that sustain injustice so that people might discover strategies to change their reality and bring about greater equity and social justice. Critical public pedagogy shares similarities with other critical educational practices. Culturally relevant pedagogy, for example, empowers students by honoring their cultures of origin and valuing their ways of speaking, acting, and knowing. Honoring the cultural, experiential knowledge of students, this pedagogical approach aims to develop a critical consciousness that enables students to challenge the dominant status quo (Gay, 2000; Ladson-Billings, 1992, 1995). With popular cultural pedagogy, educators bring popular culture into the traditional classroom in order to interrogate and criticize popular, dominant discourses (Duncan-Andrade \& Morrell, 2005; Morrell, 2002). Critical public pedagogy moves beyond the recognition of popular culture as a site for interrogating social knowledge and transcends the traditional classroom's confines to recognize cultural workers as critical educators.

Critical public pedagogy struggles against dominant discourses that sustain social injustices. It renders visible assumptive, unscrutinized beliefs: for example, familiar representational politics that support unjust power relationships and position people as "other." As such, critical public pedagogy informs critical consciousness about the meaning-making practices that legitimize existing power relations as common sense. Likewise, critical public pedagogy "attempt[s] to be discerning and attentive to those places and practices in which social agency has been denied and produced" (Giroux, 2001, p. 3). Thus, these discourses privilege subjugated social groups' perspectives and create space for counternarratives. Consequently, people encounter alternative perspectives that rearticulate and disarticulate dominant ideology, knowledge, meaning, common sense, and power relationships. By forcing these encounters, critical public pedagogy carries the potential to redirect how people look at the world, what we look at, and the value we assign to what we see. Moreover, these encounters foster questioning agents capable of identifying and dissenting against dominant constructions. These features create conditions of possibility for transformative action and thus mark critical public pedagogy as an emancipatory practice.

In sum, critical public pedagogy intervenes in civic life in order to "creat[e] those democratic public spheres where individuals can think critically, relate sympathetically to the problems of others, and intervene in the world in order to address major 
social problems" (Giroux, 2011, p. 13). Through encountering new perspectives, audiences gain opportunities "to (re)consider their understandings of themselves, their relationships with others, and the interaction of their subjectivities within society for the purposes of questioning and challenging the current political and social milieu" (Sandlin \& Milam, 2008, p. 336).

\section{Racial humor's continuum}

Humor constitutes a public pedagogy that teaches social norms, (re)produces ideology, constructs public memory, manages group affiliations and identity boundaries, and much more (Douglas, 1975; Lee, 2012; Mintz, 1988; Walker, 1998). American humor, for instance, participates in the Americanization of different ethnic groups, thereby delivering pedagogies of both exclusion and identification (Lowe, 1986). True to its pedagogical role, humor constitutes a dynamic site of interaction among competing agents and ideologies. Boskin (1997) identifies this spectrum of pedagogical work as humor's "elastic polarity": "[Humor] can operate for or against, deny or affirm, oppress or liberate" (p. 38).

Humor about race arguably represents the most confounding manifestation of this elastic polarity. While some wield racist humor as an oppressive weapon, others create critical racial humor that subverts the dominant status quo. Of course, this dichotomy between oppressive and critical humor fails to account for racial humor's complexity; rather, a continuum would illustrate better the range of racial humor. At worst, racist humor participates in a public pedagogy of domination that reproduces oppressive meanings, maintains racial divisions and hierarchies, dehumanizes those marked as "other," and sustains White privilege (Billig, 2005; Davies, 1982; Howitt \& Owusu-Bempah, 2005; Saxton, 1998; Weaver, 2011a, 2011b). At best, humor about race points out the gap between lofty ideals of equality, justice, and freedom, and the realities of discrimination, social injustice, and oppression. Comedians with marginal identities use "their 'outsider' status as a position from which to critique American institutions and values," thereby achieving "one of the central functions of American humor - to operate as a cultural corrective" (Walker, 1998, p. 33). Additionally, subordinated groups frequently deploy humor to develop community and cultivate the hope necessary to push forward toward a better future (Haggins, 2007; Krefting, 2014; Rossing, 2013; Watkins, 1994). Dance's (1998) summary of the complexities of African American women's humor exemplifies the range of racial humor on the positive end of the spectrum:

We use our humor to speak the unspeakable, to mask the attack, to get a tricky subject on the table, to warn of lines not to be crossed, to strike out at enemies and the hateful acts of friends and family, to camouflage sensitivity, to tease, to compliment, to berate, to brag, to flirt, to speculate, to gossip, to educate, to correct the lies people tell on us, to bring about change. (p. xxii)

Several variables complicate where scholars locate racial humor along this continuum. First, polysemicity makes definitive judgments about the outcomes of 
racial humor difficult, except in the most explicit instances of racism. Because racial humor is socially and historically situated, interpretations shift based on context and audience (e.g., Park, Gabbadon, \& Chernin, 2006). Second, insider/outsider status further muddies interpretations of racial humor. Dance (1998) explains, "[T]he same items that can cause raucous laughter among an all-Black audience would be very painful to a Black person in a mixed audience, who would likely respond with awkward silence and resentful anger" (p. 428). In addition, people of color have long used comic misdirection and coded language to ridicule cultural norms that could not be confronted publicly. However, the comic sensibilities that protected insider truths also served to translate the insights of double consciousness to mass audiences (Boskin, 1997; Watkins, 1994). Irony and intragroup humor prove especially difficult to pinpoint on this continuum, particularly because comedians often use the guise of humor to deflect the gravity of racist discourse (Pérez, 2013). Do White comedians who "ironically" voice racist sentiments reinforce oppressive divisions or subvert them with a knowing wink? When a comedian of color ridicules stereotypical qualities of her social group does she police social hierarchies or reclaim these qualities to foster community? ${ }^{1}$

Racial humor's track record as a pedagogy of domination and the complexities of interpretation rouse suspicion about its potential to offer a critical public pedagogy. The prevailing logic suggests that some racial humor is oppressive and that all racial humor potentially confirms racist hegemony; therefore, given these conditions, some critics remain wary of racial humor as a viable site for progressive pedagogy. Howitt and Owusu-Bempah (2005), for example, entertain the possibility of antiracist jokes but conclude that such jokes disparage racists without celebrating cultural diversity and frequently mimic the structure of racist jokes. Racial humor, however, is not a monolithic discourse, a one-dimensional enclave of racist oppression. Thus, critics must not frame racial humor as reflecting one set of interests. Essentialist arguments regarding racial humor's participation in a totalizing social structure of domination denies the agency of critical humorists struggling against the hegemonic intelligence of racism. The consequences of racist humor cannot negate emancipatory racial humor's potential as a critical public pedagogy or its participation in counterhegemonic struggle. Scholars committed to exploring popular pedagogies that sustain racial hegemony must equally investigate critical public pedagogies as forms of resistance.

The following analysis positions emancipatory racial humor as a disarming critical public pedagogy that challenges racist hegemony. I intend neither to minimize the fact that racist humor reproduces dominant ideologies nor to embrace an unequivocal celebration of all racial humor by exalting comic heroes and denying the existence of comic villains. But because the critical literature about racial humor emphasizes the villains who perpetuate dominant ideologies, we must acknowledge the lesser told story about emancipatory racial humor: specifically, its counterhegemonic possibilities as critical public pedagogy. 


\section{Emancipatory racial humor as critical public pedagogy}

Emancipatory racial humor participates in a long history of struggle against racist hegemony. Boskin (1997) writes of African American humor:

Three and a half centuries of oppression produced a particular style of resistance humor that entwined defiance, cunning, inventiveness, and retaliation. Stories, anecdotes, jokes, and pranks record [B]lack counteraction to oppression and also provide insight into the character of the oppression itself. (p. 147)

Boskin's account claims resistant racial humor raises consciousness about oppression, foregrounds a living history of counternarratives, and provides strategies for resisting oppression. In other words, humor offers a strategy for escaping, even momentarily, the bondage of racial oppression. The following analysis specifies three pedagogical functions of such emancipatory racial humor. First, revealing the "character of the oppression," critical humor exposes dominant meaning-making practices that legitimize existing power relations as common sense. Second, counterhegemonic racial humor offers defiant "counteraction to oppression" by providing a forum where counternarratives might gain a hearing. Third, emancipatory racial humor features cunning, inventive retaliation by interrogating the assumptive, naturalized racial constructions, particularly manifestations of Whiteness. These three modes of counterhegemonic struggle should be understood as neither exhaustive nor exclusive. Rather, these pedagogical interventions work together to enable a sophisticated reading of dominant public pedagogies, to honor the unique positionality of racial minorities, and to promote consciousness of the invisible knowledge regimes that support the logics of racism.

\section{Exposing dominant public pedagogies}

As a critical public pedagogy, emancipatory racial humor promotes critical readings of dominant discourses that maintain oppression. This humor renders visible the logics of hegemonic racism communicated via legal cases, media narratives, political discourse, and much more. In the riff "How old is fifteen, really?" Dave Chappelle (2004) weaves together a series of news stories to amplify racial disparities in how public culture values the lives of children. He begins with the case of singer R. Kelly urinating on a 15-year-old, then addresses the national attention dedicated to the abduction of Elizabeth Smart, a 14-year-old White girl, from her home in Utah. He contrasts these stories with the relatively ignored story of 7-year-old Erica Pratt, an African American girl kidnapped outside her Philadelphia home, who gnawed through her binding duct tape to escape her captors. Chappelle concludes with the story of Lionel Tate, a 14-year-old African American boy, tried as an adult and convicted of second-degree murder for accidentally killing his 6-year-old neighbor while practicing wrestling moves.

By recontextualizing these tragic events into a comic narrative, Chappelle interrogates the dominant public pedagogy and forces these media narratives to jostle uncomfortably, thereby revealing how they shape, define, produce, and constrain 
racial meaning in ways that sustain oppression. Chappelle uses humorous exaggeration to amplify the gross disparities between these stories. He frames Smart as lacking the sense to escape her captors for 9 months, yet he lionizes Pratt when he jokes, "Kidnapped at 4 o'clock and back home watching herself on the news at 5:30!" He concludes with the punchline: "If you think it's ok to give a fifteen-year-old life in jail, then it's ok to pee on 'em." These dominant public pedagogies intertwine to expose a pernicious disparity in the value of Black youths' lives. In other words, the routine illuminates unjust incongruities related to public judgments regarding innocence, value, and criminality. Chappelle's comedic bricolage edifies the audience about the dominant public pedagogies that disregard people of color while masquerading as common sense. As such, this pedagogical text offers emancipatory lessons that carry the potential to empower questioning agents capable of identifying problems, analyzing their cultural roots, and discovering strategies to dissent against dominant racial ideologies.

Similarly, following the shooting of Michael Brown in Ferguson, Missouri, The Daily Show with Jon Stewart exposed and critiqued dominant postracial discourses through a series of comic incongruities that challenged the validity of this prevailing logic. In a report titled "Race/Off," Stewart explains that the story in Ferguson "has a lot of people outraged and upset" (Stewart \& Albanese, 2014). "Of course!" he affirms, "An unarmed Black teenager gunned down in the street by police under suspicious circumstances?" The case demands outrage, he suggests, with comic misdirection that amplifies the subsequent reversals. Stewart highlights outrage against race-conscious reactions to the tragedy, such as an analyst lamenting how the description of "an unarmed Black teenager shot by a White cop" regrettably "colors the way we look at the story." Several other pundits imply "reverse racism" by asking, "Why aren't we covering Black-on-Black crime?" Stewart plays the comic fool and reacts incredulously to these protestations, thereby heightening their incongruity to the outrage he implicitly foregrounded. The rancor climaxes with a montage of postracial proclamations from major news outlets:

A lot of people are trying to make this about Black and White and trying to make this about race." - "This is part of this effort to make everything about race." - "Is this a story about race? Do we know that?" - "I think it's playing the race card, and I think it's disgraceful!" - "The only racial divide that is being created here is being created by the race-baiters." - "You know who talks about race? Racists!

With ample evidence documenting this dominant pedagogy of postracialism, Stewart continues with a sequence of comic juxtapositions that challenge these dominant discourses. First, comparing the colorblind outrage to childish ribbing about flatulence, Stewart retorts, “Did you just 'He who smelt it, dealt it' racism?!” But Stewart's comic persona immediately shifts from the childish fool to the sharp-tongued satirist when he offers rapid-fire statistics and stories about Ferguson that evince significant racial disparities and discredit the postracial frame. For example, he 
presents the story of Henry Davis, charged with damaging government property after his blood soiled the uniforms of the Ferguson police who beat him. With a nod toward concerns about police militarization, Stewart's comic personas merge to underscore this racial injustice: "Let me get this straight. You guys got tanks, but you can't keep a couple of Tide Sticks around?" Next, Stewart juxtaposes the outrage over "race baiting" with many of the same pundits' furor over a "War on Christmas." "Remember?" he urges, "You were furious that America's eleven-month long celebration of Christmas wasn't enough." Against this alleged affront to Christianity, Stewart juxtaposes the broader context of racist hegemony that Ferguson symbolizes: the indignities people of color face "from the ridiculous to the grotesque to the sometimes fatal." His final reversal is one of tone. He sets aside his mixture of foolishness, hyperbole, and satire, and confronts these postracial pulpiteers in all seriousness: "You're tired of hearing about [racism]? Imagine how fucking exhausting it is living it!" This last juxtaposition returns the audience to the outrage intimated at the outset: no longer a hint, but a performed reality. Through these reversals and juxtapositions, Stewart models a critical consciousness necessary to identify, expose, and refute the postracial discourses that protect hegemonic racism.

\section{Foregrounding counternarratives}

Emancipatory racial humor not only exposes dominant pedagogies but also carves out discursive spaces in which counternarratives talk back to dominant discourses. ${ }^{2}$ Dominant modes of production frequently privilege White experiences while denying marginal voices the space to assert experiential truths. The consistent lack of racial diversity on the popular sketch comedy series Saturday Night Live illustrates this challenge. In fact, for several decades, late-night comedy and satire in the United States has featured predominantly White men. Most comedians of color who have broken into this club - Wanda Sykes, George Lopez, David Allen Grier, D. L. Hughley - found their presence in late-night comedy short lived. ${ }^{3}$ In this context, emancipatory racial humor provides an outlet for truths otherwise suppressed within popular, public discourse. As Krefting (2014) asserts, critical humorists "inform and instruct audiences about citizenship, politics, the law, and social interaction from the perspectives of minority communities" (p. 70). Such humor honors the experiential knowledge of subjugated communities. Moreover, humor creates relationships between artist and audience that allow people to "receive the artist's view of one or another fragment of reality" in order to "catalyze new awarenesses" of reality (Olson, 1988, p. 110).

The following instances of truth-telling racial humor exemplify how such critical public pedagogy privileges subordinated experiences and counternarratives. In That Nigger's Crazy (1974), Richard Pryor uses a narrative about a routine traffic stop to address White audience members who "don't believe cops degrade" Black people. He cautiously reaches for his wallet while proclaiming, "I am reaching into my pocket for my license!" before justifying to the audience, "I don't want to be no motherfuckin' accident." In Jesus Is Black (Mooney, 2007), Paul Mooney claims "[Black people] all have a police story." He shares the degrading, guilt-assuming questions 
he might receive during a traffic stop: "Are you on probation or parole?" and "Does the owner of this car know you have it?" Similarly, in Killin' Them Softly (2000), Dave Chappelle attests to Black culture's inherent suspicion of police. He asks a White audience member whether police ask for her license and registration when they pull her over. "I'm just guessing," Chappelle explains, “That's not what they say to us. [Imitating a police officer] 'Spread your cheeks and lift your sack!' He continues: "Every Black dude in this room is a qualified paralegal ... If one of us even start to do something wrong an old Black man will pop out of nowhere: 'Nigga don't do that! That's five to ten [years]!" He punctuates this suspicion by explaining his refusal to call police after a break-in at his home. He feared the police would suspect him of the robbery and put his life at risk with "necessary force." Again imitating an officer, he jests: "Apparently this nigger broke in and hung pictures of his family everywhere!" In her Sick and Tired (Sykes, 2006) performance, Wanda Sykes attests to the thoroughness of dominant public pedagogies by claiming that even Black people racially profile: "If we see a Black man running down the street we like, 'What the hell did he just do?' It just makes us all look bad." After a beat, she adds, "Run, brother! Run!" Lest the audience feel too self-assured that "everybody does it," her subversive cheer underscores the different lived experiences with and reactions to law enforcement.

These stories ground ideological struggle in marginalized subjects' lived experiences; humor affords a public space for these narratives. As Haggins (2007) claims, humor provides a forum "for the unfiltered venting of cultural and political anger" - a strategy for "howling about oppression and subjugation" (p. 4). Thus, humor allows these artists to reclaim their agency, assert their voice, and affirm their experiential knowledge. Such truth-telling racial humor exemplifies what Alexander (2004) calls "giving skin" - drawing attention to the expectations, limitations, identifications, emotions, and truths of racialized experiences (p. 16). These artists construct shared knowledge regarding the ways racial oppression "tempers your tongue, articulates your vision and sometimes even dictates your body in time and place" (p. 15). Their personal experiences with oppression, excluded from dominant narratives, counter prevailing wisdom about the justice system and affirm shared experiences of oppression. Consequently, they bring new perspectives to public consciousness with the potential to disrupt the terms of subordination. For example, these artists promote understanding - or at minimum, recognition - of the tragedy accompanying their narratives. Public culture often links "tragedy" only to physical death or explicit violence. However, these counternarratives' collective weight broadens the scope of tragedy to include invisibility, erasure, devaluation, and dehumanization. In essence, these comic voices attest to tragedies such as physical death and the tragedy in what Williams (1991) calls "spirit murder": a "disregard for others whose lives qualitatively depend on our regard” (p. 73). These artists' critical public pedagogy teaches audiences to feel rage about a range of tragedies from egregious racism to daily racial experience. Enlarging the tragedy of racism invites audiences to identify and interrupt the maturation of racism in the most basic undertakings of everyday life. 


\section{Subverting the "natural"}

Finally, emancipatory racial humor recontextualizes dominant narratives so as to subvert assumptive elements of racial hegemony, and in particular manifestations of Whiteness. This humor performs what could be called "comic jujitsu": a technique by which artists leverage an opponent's power in order to neutralize or defeat that opponent. Rather than directly attacking the privileges of Whiteness and the dominant narratives of racial oppression, humor manipulates these forces against themselves.

In the wake of Trayvon Martin's death in 2012, comedians Keegan-Michael Key and Jordan Peele addressed racial profiling on their Comedy Central series Key \& Peele (Key, Peele, Martel, Roberts, \& Zadak, 2013). Peele, who is biracial, walks through a suburban neighborhood while wearing a hoodie. He smiles at two White children playing in their front yard: They freeze fearfully before their mother rushes them inside the house. He politely nods at a White male who glares back contemptuously. A police cruiser approaches Peele; the officer prepares for confrontation. As if wishing to become invisible amid the palpable hostility, Peele pulls his hood over his head. As the police car pulls beside him, the comic subversion arrives: Printed on the hood is the profile of a young, White male. The police officer falls for the decoy: His threatening gaze becomes a carefree smile as he drives away. Whiteness saves Peele.

This comic sketch interrogates equally both oppressive constructions of Blackness as a threat to White society and White privilege. First, the sequence foregrounds oppressive racial meaning constructions. The fearful glances from suburban families suggest White suburban spaces construct Blackness as intrinsically suspect. The police officer's gaze dramatizes the ways institutions criminalize Black racial subjects. However, Peele's cunning disguise directs attention both to racism against people of color and to racism operating for White advantage. The sketch highlights spaces and institutions that grant Whiteness the privileged presumption of universal belonging and innocence. Donning a White mask to become invisible, Peele simultaneously unmasks Whiteness and renders its privileges visible.

A final example illustrates how emancipatory racial humor's critical pedagogical strategies work in concert to challenge the dominant public pedagogies of racism. A report titled "Frisky Business" on The Daily Show with Jon Stewart confronted New York City's stop-and-frisk policy, which disproportionately targeted Black and Latino residents by NYPD officers (Stewart \& Albanese, 2013). Host John Oliver introduced the topic with a stark contrast of racial perspectives: "For years, opinion on [stop-and-frisk] has been divided, with Black and Latino residents of this city saying it's an invasion of their liberty, and White residents saying, 'Oh, I think I heard a thing about that on NPR [National Public Radio]. Is that still happening?'” The juxtaposed perspectives call attention to the disparity of experience with stop-and-frisk and foreground a cavalier postracial consciousness that ignores such realities. The satirical jab simultaneously exposes the marginalization of racialized truths and values those counternarratives. First, Oliver addresses White audience members when he compares stop-and-frisk to Transportation Security Administration (TSA) workers "patting [White people] down, unnecessarily delaying us, looking for weapons which 
we obviously don't have, and we're just trying to get to our gate." He extends the analogy: "Imagine your whole neighborhood is Terminal B at LaGuardia [Airport in New York City]. And the TSA agents sometimes talk to you like this: [yelling] 'What the fuck are you looking at?! Open up that computer bag before I break your arm motherfucker!' Irritating isn't it? It's a little irritating." Oliver contrasts "irritation" with a damning montage of news clips depicting humiliating, fear-inducing, and violent stop-and-frisk detainments. The hyperbolic performance of the TSA agent and the ironic understatement regarding such "irritating" treatment juxtapose sharply with the severe racial consequences of the stop-and-frisk policy. This tension challenges White racial subjects to recognize both their privileged protection from such heightened scrutiny and the perpetual criminalization of racial minorities.

The segment also recontextualizes the troubling stop-and-frisk policy in ways that subvert naturalized privileges of Whiteness. Correspondent Jessica Williams reports from "one of New York's most crime ridden neighborhoods - Wall Street." Arguing she feels unsafe, Williams demands police stop any potential white-collar criminals, then she describes the suspects' profile: "tailored suits, slicked back hair, always need sunscreen, if you know what I'm saying." Oliver, a White male, protests her characterization, but Williams retorts, "If you don't want to be associated with white-collar crime, maybe you shouldn't dress that way!" Williams plays with common public discourses that employ racially coded language that blames victims for their oppressive conditions. Repurposing these discursive practices for White businessmen unsettles audience investments in the invisibility of Whiteness. Williams first exposes unexamined Whiteness and then leverages its power to destabilize its privileged protections.

Both the "Frisky Business" report and Jordan Peele's trickster-like disguise expose contradictions between the criminality we fear and the criminality we forgive. Such destabilizing power reversals prove central to critical public pedagogy. Through humorous disruptions, they indict institutional racism, White privilege, apathy, and postracial ignorance, thereby rendering them a primary focus of inquiry. These texts invite discernment about dominant narratives, cultural practices, and spaces that devalue people of color and protect Whiteness as natural, civil, proper, and safe. Comic jujitsu frustrates normalized power relationships, if only momentarily, by opening up opportunities to neutralize racial injustice or even reimagine more just relationships. They purposefully refuse the dominant racial identity constructions and provoke audiences to reimagine racial identities, power relationships, and social value.

\section{Circulation and production}

Critical public pedagogy locates critical work within media production and circulation practices, and, to be sure, production and circulation practices restrict racial humor in public discourse. Commercial constraints, messages mainstreamed for mass consumption, and interpretive variance constrain emancipatory racial humor's transformative work. Krefting (2014) invokes the metaphor of "charged" humor to describe 
critical, justice-oriented humor that polarizes, excites, attracts and repels, and always comes with a cost. Specifically, the production and consumption economy rejects polarizing humor; consequently, critical comics encounter pushback for material that might jeopardize advertising revenue or that will not appeal to the broadest audience demographics. Haggins (2007) documented this trend in her analysis of Black comedians whose critical edge was dulled by industrial limitations and mainstream norms. However, critical public pedagogy also attends to people's construction of a discursive space where counternarratives circulate amid dominant public discourses. Borrowing from Sandlin and Milam's (2008) discussion of culture jammers as critical public pedagogues, the public in critical public pedagogy includes cultural workers, immediate audiences, extended communities who encounter these texts (or textual fragments) indirectly, and new textual artifacts that emerge from these civic interactions. Thus, contemporary circulation of critical humor fragments animate opportunities for people to engage one another regarding the social problems addressed by a given text.

Certainly, a single skit or stand-up act cannot unilaterally interrupt hegemonic racism. However, the critical public pedagogy curriculum comprises a multifaceted stream of stand-up comedy, sketch comedy, news satires, and much more that regularly circulate in popular, mainstream outlets. Of the fragments considered here, for example, several come from feature-length comedy specials produced for mainstream cable networks Comedy Central, Home Box Office, and Showtime. Chappelle's Show, Key \& Peele, and The Daily Show with Jon Stewart all enjoyed great commercial success on Comedy Central. In addition to the critical fragments considered here, humorists such as Hari Kondabolu, whose comedy features strong antiracist and anticolonial themes, appear on major network late-night shows such as Conan, Jimmy Kimmel Live!, and The Late Show with David Letterman. W. Kamau Bell's critical race humor gained the backing of the FX network with his show Totally Biased with W. Kamau Bell. Such mainstream popularity confirms both that the critical counternarratives resonate with broader experience of discrimination and that dominant social groups willingly engage these stories. Thus, these artists capitalize on dominant modes of production and circulation to advance a counterhegemonic narrative about racial oppression.

Second, the short fragments (under ten minutes) considered in this essay easily repeat, circulate, and accumulate across multiple discursive sites. These fragments find new audiences on major cable television outlets, YouTube, Twitter, Facebook, and online popular news outlets such as Huffington Post and BuzzFeed. The lessons recirculate through shared links, retweets, likes, and blog posts that continue to deliver these sketches to expanding audiences. The circulation of comic discourses after Trayvon Martin's death provides a good example. The Daily Show with Jon Stewart featured at least seven different segments between March 2012 and August 2013 about Martin's death and George Zimmerman's trial. After their initial airing on Comedy Central, these fragments extended their reach on websites such as Huffington Post, Buzzfeed, Real Clear Politics, mediaite.com, variety.com, gawker.com, and many more. Clips from Comedy Central's The Colbert Report and Key \& Peele 
and from FX's Totally Biased with W. Kamau Bell enjoyed similar circulation and attention. Similarly, after the Michael Brown and Eric Garner cases in fall 2014, Essence.com featured " 11 times comedians got it right about race and police brutality" (Doggett \& Sangweni, 2014) and included links to YouTube fragments, thereby reanimating comic voices as participants in an ongoing struggle over racism. In sum, understanding emancipatory racial humor as critical public pedagogy recognizes a counterhegemonic curriculum comprising a vast repository of bits circulating to broad audiences across multiple media and social networks.

\section{Coalition and community}

Emancipatory racial humor understood as a critical public pedagogy carries the potential to disrupt racist hegemony and free us from its grip. Despite the persistence of racist humor and the complications of competing interpretive communities, critical humorists consistently challenge the injustices of racism. The artists considered here make visible the representational politics, dominant narratives, and other meaning-making practices that (re)produce racial knowledge and sustain the racial oppression. Critical artists create space within public discourse for counternarratives that both rearticulate and disarticulate dominant ideology. These artists' insights challenge common sense worldviews sustaining racial injustice. As such, emancipatory racial humor possesses the potential to throw off-balance power relations and structures animating racism. Circulating and recirculating, these comic fragments as critical public pedagogy create conditions for critical consciousness of the dominant public pedagogies, of the tragic spirit murder these dominant narratives enable, and of the invisible privileges of racial hegemony.

Emancipatory racial humor is no panacea. It will not achieve progressive transformation alone. Thus, emancipatory racial humor's potential as critical public pedagogy rests not only in developing critical consciousness but also in creating communities and coalitions. When dominant narratives perpetuate dehumanizing frames, emancipatory racial humor affirms collective identities, thereby conferring value to marginalized groups and validating shared experiences and struggles. Moreover, emphasizing the community building possibilities of critical race humor transforms the limitations of polysemy into an opportunity. Racial comedy creates opportunities "for interrogating and critiquing racial ideologies and injustices precisely because of the ambiguity and contingency ... which provoke important conversations about race" (Rossing, 2011, pp. 423-424). That is, alternative readings create possibilities for new communities as people connect and engage with one another over the comic texts. Emancipatory racial humor, therefore, invites citizens to engage one another in communal politics as they make sense of the comedy itself, then as they talk back to dominant discourses - whether they find the comic fragment to confirm or undermine dominant meanings. Thus, it provides opportunities for interaction and relationship that may yield communities of progressive cultural (re)production. 
Emancipatory racial humor also promotes coalition among groups united around the counterhegemonic struggles in which these humorists participate. The need for critical alliances across multiple fronts of cultural work lies at stake. Communication critics vigilantly guard against the dominant public pedagogies that reinforce oppressive ideologies and serve the interests of the status quo. Yet fewer models exist for seizing on creative critical humor as a partner for sociopolitical transformation. The relationship between critical scholars and popular, public pedagogies must be further explored so that we might capitalize on possibilities for social transformation. Positioning emancipatory racial humor as a critical public pedagogy encourages humorists, critical educators, and scholars to complement one another's efforts for such racial justice rather than struggling in isolation. Working at arms' distance from other critical, cultural workers diminishes the power of the critical voice.

Just as progressive humorists' creative work alone will not create cultural transformation, neither will our critical scholarship. Thus, scholars engaged in critical cultural studies must take seriously emancipatory racial humor's capacity to facilitate an empowered community engaged in sociopolitical struggle. In a culture that prefers silence and solemnity vis-à-vis race, where formal educational discourses about racial injustice strain to gain a hearing, audiences reward critical race humorists with attention and applause. When postracial ideologies squelch racial experience, emancipatory racial humor loudly reasserts its salience. Insofar, as it may sharpen consciousness of domination and inspire audiences toward transformative action, emancipatory racial humor requires serious consideration as a partner in the struggle against racial injustice.

\section{Acknowledgments}

Jonathan P. Rossing (Ph.D., Indiana University, 2010) is an Assistant Professor in the Communication Studies Department in the Indiana University School of Liberal Arts at Indiana University Purdue University, Indianapolis. An earlier version of this paper was presented at the National Communication Association Convention in 2014 in Chicago. The author thanks M. Lane Bruner, Rachel Griffin, Kristen Hoerl, Casey Kelly, Kristin Swenson, Andrea Rossing McDowell, and the reviewers for their constructive and challenging feedback at various iterations of this essay.

\section{Notes}

1 On questions of interpretation and inside/outsider humor, see: Friedman, 2014; Rappoport, 2005; Rossing, 2012; Watkins, 1994; Weaver, 2011b. While the interpretive complexities of racial humor and its diverse audiences are not the primary focus of this essay, the following examples offer several representative examples of these tensions. Chris Rock's frequently discussed "Black people vs. niggas" routine from Bring the Pain (1998) offers an interesting example of insider humor that many understood to reinforce dominant, racist stereotypes. Playing off Rock's routine and further highlighting the challenges of interpretation and insider/outsider dynamics, the television series The Office 
featured an episode in which the office staff receives mandatory diversity training after boss Michael Scott (Steve Carrell) reenacts Rock's monologue for his coworkers ("Diversity Day"). Dave Chappelle's sudden exit from his popular Comedy Central series Chappelle's Show also illustrates the messy interpretive terrain of racial humor. Chappelle worried that his jokes were not being received as intended by White audience members. Additionally, late night satirist Stephen Colbert found himself the target of a \#CancelColbert campaign on Twitter after his show tweeted a joke that appeared to mock Asian Americans. The joke was part of a larger satirical bit that skewered the owner of the Washington, DC, professional football franchise for his refusal to stop using "Redskins" in the team name.

2 Griffin (2013) presents a related argument about Black Feminist Thought as a critical public pedagogy that provides a "tactical means to secure a discursive space for Black women to speak for and define themselves" (p. 78).

3 Since this essay has moved toward publication, Comedy Central's late-night line up has changed. The Nightly Show with Larry Wilmore premiered in January 2015, and South African comedian Trevor Noah has been announced as the next host of The Daily Show.

\section{References}

Alexander, B. K. (2004). Racializing identity: Performance, pedagogy, and regret. Cultural Studies/Critical Methodologies, 4(1), 12-27. doi: 10.1177/1532708603251810.

Alexander, M. (2010). The new Jim Crow: Mass incarceration in the age of colorblindness. New York, NY: New Press.

Billig, M. (2005). Comic racism and violence. In S. Lockyer \& M. Pickering (Eds.), Beyond a joke: The limits of humour (pp. 25-44). Basingstoke, England: Palgrave Macmillan.

Boskin, J. (Ed.) (1997). The humor prism in 20th-century America. Detroit, MI: Wayne State University Press.

Chappelle, D. (2000). Killin' them softly. New York, NY: Home Box Office.

Chappelle, D. (2004). For what it's worth. New York, NY: Pilot Boy Productions.

Dance, D. C. (Ed.) (1998). Honey hush! An anthology of African American women's humor.

New York, NY: W. W. Norton \& Company.

Darling-Hammond, L. (2004). The color line in American education: Race, resources, and student achievement. Du Bois Review, 1(2), 213-246. doi: 10.1017/S1742058X0404202X.

Davies, C. (1982). Ethnic jokes, moral values and social boundaries. British Journal of Sociology, 33(3), 383-403.

Denzin, N. K. (2003). Screening race. Cultural Studies/Critical Methodologies, 3(1), 22-43.

Dimitriadis, G. (2001). Pedagogy and performance in Black popular culture. Cultural Studies/Critical Methodologies, 1(1), 24-35.

Doggett, J. A., \& Sangweni, Y. (2014, December 8). 11 times comedians got it right about race and police brutality. Essence [Electronic resource]. Retrieved from http://www.essence.com/2014/12/08/comedians-on-race-police-brutality/

Douglas, M. (1975). Jokes. In M. Douglas (Ed.), Implicit meanings: Essays in anthropology (pp. $90-115)$. New York, NY: Routledge.

Duncan-Andrade, J. M. R., \& Morrell, E. (2005). Turn up that radio, teacher: Popular cultural pedagogy in new century urban schools. Journal of School Leadership, 15, 284-308. 
Enck-Wanzer, S. M. (2009). All's fair in love and sport: Black masculinity and domestic violence in the news. Communication and Critical/Cultural Studies, 6(1), 1-18. doi: $10.1080 / 14791420802632087$.

Freire, P. (2000/1970). Pedagogy of the oppressed. New York, NY: Continuum.

Friedman, S. (2014). Comedy and distinction: The cultural currency of a "good" sense of humor. New York, NY: Routledge.

Gay, G. (2000). Culturally responsive teaching. New York, NY: Teachers College Press.

Giroux, H. A. (2000). Public pedagogy as cultural politics: Stuart Hall and the "crisis" of culture. Cultural Studies, 14(2), 341-360.

Giroux, H. A. (2001). Cultural studies as performative politics. Cultural Studies/Critical Methodologies, 1(1), 5-23. doi: 10.1177/153270860100100102.

Giroux, H. A. (2003). Public spaces, private lives: Democracy beyond 9/11. Lanham, MD: Rowman and Littlefield.

Giroux, H. A. (2011). On critical pedagogy. New York, NY: Continuum Press.

Griffin, R. A. (2013). Gender violence and the Black female body: The enduring significance of "crazy" Mike Tyson. Howard Journal of Communications, 24(1), 71-94. doi: 10.1080/10646175.2013.748602.

Griffin, R. A. (2015). Problematic representations of strategic Whiteness and "post-racial" pedagdogy: A critical intercultural reading of The Help. Journal of International and Intercultural Communication, 8(2), 147-166. doi: 10.1080/17513057.2015.1025330.

Grossberg, L. (1994). Bringing it all back home-Pedagogy and cultural studies. In H. A. Giroux \& P. McLaren (Eds.), Between borders: Pedagogy and the politics of cultural studies (pp. 1-25). New York, NY: Routledge.

Grossberg, L. (1996). Toward a genealogy of the state of cultural studies. In C. Nelson \& D. P. Gaonkar (Eds.), Disciplinarity and dissent in cultural studies (pp. 87-107). New York, NY: Routledge.

Haggins, B. (2007). Laughing mad: The Black comic persona in post-soul America. New Brunswick, NJ: Rutgers University Press.

Hall, S. (1997). Representation: Cultural representations and signifying practices. Thousand Oaks, CA: SAGE.

hooks, b. (1995). Performance practice as a site of opposition. In C. Ugwu (Ed.), Let's get it on: The politics of Black performance (pp. 210-221). Seattle, WA: Bay Press.

Howitt, D., \& Owusu-Bempah, K. (2005). Race and ethnicity in popular humour. In S. Lockyer \& M. Pickering (Eds.), Beyond a joke: The limits of humour (pp. 45-62). Basingstoke, England: Palgrave Macmillan.

Key, K. M., Peele, J., Martel, J., Roberts, I., \& Zadak, J. (Executive Producers). (2013, September 18). Key \& Peele. Episode 301. New York, NY: Comedy Central.

Krefting, R. (2014). All joking aside: American humor and its discontents. Baltimore, MD: Johns Hopkins University Press.

Ladson-Billings, G. (1992). Culturally relevant teaching: The key to making multicultural education work. In C. A. Grant (Ed.), Research and multicultural education (pp. 106 -121). London, England: Falmer Press.

Ladson-Billings, G. (1995). But that's just good teaching! The case for culturally relevant pedagogy. Theory Into Practice, 34(3), 159-165.

Lee, J. Y. (2012). Twain's brand: Humor in contemporary American culture. Jackson: University Press of Mississippi. 
Lefcourt, H. M. (2001). Humor: The psychology of living buoyantly. New York, NY: Kluwer Academic.

Lipsitz, G. (1990). Time passages: Collective memory and American popular culture. Minneapolis: University of Minnesota Press.

Lipsitz, G. (2011). How racism takes place. Philadelphia, PA: Temple University Press.

López, I. H. (2006). White by law: The legal construction of race. New York: New York University Press.

López, I. H. (2014). Dog whistle politics: How coded racial appeals have reinvented racism and wrecked the middle class. New York, NY: Oxford University Press.

Lowe, A. (1986). Theories of ethnic humor: How to enter, laughing. American Quarterly, 38(3), 439-460.

McLaren, P. (1989). Life in schools. White Plains, NY: Longman.

Mintz, L. E. (Ed.) (1988). Humor in America: A research guide to genres and topics. Westport, CT: Greenwood Press.

Mooney, P. (2007). Jesus is Black - So was Cleopatra: Know your history. New York, NY: Momentum.

Morreall, J. (1983). Taking laughter seriously. Albany: State University of New York Press.

Morrell, E. (2002). Toward a critical pedagogy of popular culture: Literacy development among urban youth. Journal of Adolescent and Adult Literacy, 46(1), 72-77.

Morris, E. W. (2005). “Tuck in that shirt!” Race, class, gender, and discipline in an urban school. Sociological Perspectives, 48(1), 25-48.

Mukherjee, R. (2014). Antiracism limited: A pre-history of post-race. Cultural Studies, 2014, $1-31$.

Olson, S. K. (1988). Standup comedy. In L. E. Mintz (Ed.), Humor in America: A research guide to genres and topics (pp. 109-136). Westport, CT: Greenwood Press.

Park, J. H., Gabbadon, N. G., \& Chernin, A. R. (2006). Naturalizing racial differences through comedy: Asian, Black, and White views on racial stereotypes in Rush Hour 2. Journal of Communication, 56(1), 157-177. doi: 10.1111/j.1460-2466.2006.00008.x.

Pérez, R. (2013). Learning to make racism funny in the "color-blind" era: Stand-up comedy students, performance strategies and the (re)production of racist jokes in public. Discourse and Society, 24(4), 478-503. doi: 10.1177/0957926513482066.

Pryor, R. (1974). That nigger's crazy. New York, NY: Reprise Records.

Rappoport, L. (2005). Punchlines: The case for racial, ethnic, and gender humor. Westport, CT: Praeger.

Rossing, J. P. (2011). Comic provocations in racial culture: Barack Obama and "The Politics of Fear." Communication Studies, 62(4), 422 - 438. doi: 10.1080/10510974.2011.588077.

Rossing, J. P. (2012). Deconstructing postracialism: Humor as critical, cultural project. Journal of Communication Inquiry, 36(1), 44-61. doi: 10.1177/0196859911430753.

Rossing, J. P. (2013). Dick Gregory and activist style: Identifying attributes of humor necessary for activist advocacy. Argumentation and Advocacy, 50 (Fall), 59-71.

Sandlin, J. A. (2007). Popular culture, cultural resistance, and anticonsumption activism: An explanation of culture jamming as critical adult education. New Directions for Adult and Continuing Adult Education, 115, 73-82.

Sandlin, J. A., \& Milam, J. L. (2008). "Mixing pop (culture) and politics": Cultural resistance, culture jamming, and anti-consumption activism as critical public pedagogy. Curriculum Inquiry, 38(3), 323-350. doi: 10.1111/j.1467-873X.2008.00411.x. 
Sandlin, J. A., O’Malley, M. P., \& Burdick, J. (2011). Mapping the complexity of public pedagogy scholarship: 1894-2010. Review of Educational Research, 81(3), 338-375. doi: $10.3102 / 0034654311413395$.

Saxton, A. (1998). Blackface minstrelsy, vernacular comics, and the politics of slavery in the north. In D. Roediger \& M. H. Blatt (Eds.), The meaning of slavery in the North (pp. 157 -175). New York, NY: Garland Publishing.

Squires, C. (2014). The post-racial mystique: Media and race in the twenty-first century. New York: New York University Press.

Stewart, J., \& Albanese, R. [Executive Producers]. (2013, August 13). The Daily Show with Jon Stewart [Television series]. New York, NY: Comedy Central.

Stewart, J., \& Albanese, R. [Executive Producers]. (2014, August 26). The Daily Show with Jon Stewart [Television series]. New York, NY: Comedy Central.

Storey, J. (2006). Cultural theory and popular culture (4th ed.). Athens: University of Georgia Press.

Sykes, W. (2006). Sick and tired. New York, NY: Home Box Office.

Walker, N. A. (1998). What's so funny? Humor in American culture. Baltimore, MD: Rowman and Littlefield.

Watkins, M. (1994). On the real side: A history of African American comedy from slavery to Chris Rock. Chicago, IL: Lawrence Hill Books.

Weaver, S. (2011a). Jokes, rhetoric and embodied racism: A rhetorical discourse analysis of the logics of racist jokes on the Internet. Ethnicities, 11(4), 413-435. doi: $10.1177 /$ 1468796814548233.

Weaver, S. (2011b). The rhetoric of racist humour: US, UK and global race joking. Burlington, VT: Ashgate.

Williams, R. (1967). Communications (3rd ed.). New York, NY: Barnes and Noble.

Williams, P. (1991). The alchemy of race and rights. Cambridge, MA: Harvard University Press.

Yousman, B. (2009). Inside $O z$ : Hyperviolence, race and class nightmares, and the engrossing spectacles of terror. Communication and Critical/Cultural Studies, 6(3), 265-284.

doi: 10.1080/14791420903049728. 